Article

\title{
Experimental and Theoretical Study of the Interactions between $\mathrm{Fe}_{2} \mathrm{O}_{3} / \mathrm{Al}_{2} \mathrm{O}_{3}$ and $\mathrm{CO}$
}

\author{
Zhiyong Liang, Wu Qin * and Changqing Dong *
}

National Engineering Laboratory for Biomass Power Generation Equipment, School of Energy, Power and Mechanical Engineering, North China Electric Power University, Beijing 102206, China; junjinxing@163.com

* Correspondence: qinwu@ncepu.edu.cn (W.Q.); cqdong1@163.com; (C.D.); Tel./Fax: +86-10-6177-2030 (W.Q.)

Academic Editor: Gustavo A. Fimbres Weihs

Received: 5 December 2016; Accepted: 25 April 2017; Published: 29 April 2017

\begin{abstract}
The behavior of $\mathrm{Fe}_{2} \mathrm{O}_{3} / \mathrm{Al}_{2} \mathrm{O}_{3}$ particles as oxygen carriers (OCs) for $\mathrm{CO}$ chemical looping combustion (CLC) under different reaction temperatures $\left(700{ }^{\circ} \mathrm{C}, 800{ }^{\circ} \mathrm{C}, 900{ }^{\circ} \mathrm{C}\right.$, and $1000{ }^{\circ} \mathrm{C}$ ) were tested in a lab-scale fluidized bed and a thermogravimetric analysis (TGA) unit. The results show that the oxygen carrier presents the highest reactivity at $800^{\circ} \mathrm{C}$, even after 30 cycles of redox reaction in a fluidized bed, while more obvious carbon deposition occurred for the case at $700{ }^{\circ} \mathrm{C}$, and agglomeration for the case at $1000^{\circ} \mathrm{C}$. Moreover, the detailed behavior of the prepared $\mathrm{Fe}_{2} \mathrm{O}_{3} / \mathrm{Al}_{2} \mathrm{O}_{3}$ particle was detected in the TGA apparatus at different reaction temperatures. Furthermore, temperature-programming TGA experiments were performed to investigate the influence of different $\mathrm{CO}$ concentrations and $\mathrm{CO} / \mathrm{CO}_{2}$ concentrations on the reaction between $\mathrm{CO}$ and $\mathrm{OC}$ during the chemical looping combustion processes. Based on these experimental behaviors of the prepared $\mathrm{Fe}_{2} \mathrm{O}_{3} / \mathrm{Al}_{2} \mathrm{O}_{3}$ during the $\mathrm{CLC}$ of $\mathrm{CO}$, the detailed models and electronic properties of the pure and reduced $\mathrm{Fe}_{2} \mathrm{O}_{3} / \mathrm{Al}_{2} \mathrm{O}_{3}$ supported the slabs, $\mathrm{CO}$ adsorption, and oxidation, and the decomposition reactions on these surfaces were revealed using density functional theory (DFT) calculations which went deep into the nature of the synergetic effect of the support of $\mathrm{Al}_{2} \mathrm{O}_{3}$ on the activity of $\mathrm{Fe}_{2} \mathrm{O}_{3}$ for the CLC of CO.
\end{abstract}

Keywords: density functional theory (DFT); $\mathrm{CO}_{2}$ capture; chemical looping combustion (CLC); iron oxide

\section{Introduction}

Recently, chemical looping combustion (CLC) has been suggested as an effective technology to capture $\mathrm{CO}_{2}$ without extra energy consumption and with nearly zero emission of pollutants [1,2]. The system contains two interconnected reactors: the fuel reactor (FR) and the air reactor (AR), as depicted in Figure 1. In the FR, fossil fuel is oxidized into $\mathrm{CO}_{2}$ and $\mathrm{H}_{2} \mathrm{O}$ by an oxygen carrier (OC), while the $\mathrm{OC}$ is reduced to lower valence states (see Reaction 1). After that, the reduced $\mathrm{OC}$ is transferred to the $\mathrm{AR}$, and is oxidized into its original state by air (Reaction 2). The outlet gases from the FR are mainly $\mathrm{CO}_{2}$ and $\mathrm{H}_{2} \mathrm{O}$, which can be easily separated by condensing and drying to obtain a high concentration of $\mathrm{CO}_{2}$ [3-5]. Although Reaction 1 is often endothermic, Reaction 2 is exothermic and therefore the oxidized OC can also act as a heat carrier to transfer the energy needed to maintain the reduction reaction that has happened in the FR. Furthermore, the total amount of heat obtained from the CLC system is even more than that of conventional combustion because of the lower irreversibility of the two reaction courses [6,7].

$$
\begin{gathered}
(2 n+m) \mathrm{M}_{x} \mathrm{O}_{y}+\mathrm{C}_{n} \mathrm{H}_{2 m} \rightarrow(2 n+m) \mathrm{M}_{x} \mathrm{O}_{y-1}+m \mathrm{H}_{2} \mathrm{O}+n \mathrm{CO}_{2} \\
2 \mathrm{M}_{x} \mathrm{O}_{y-1}+\mathrm{O}_{2} \text { (Air) } \rightarrow \mathrm{M}_{x} \mathrm{O}_{y}
\end{gathered}
$$




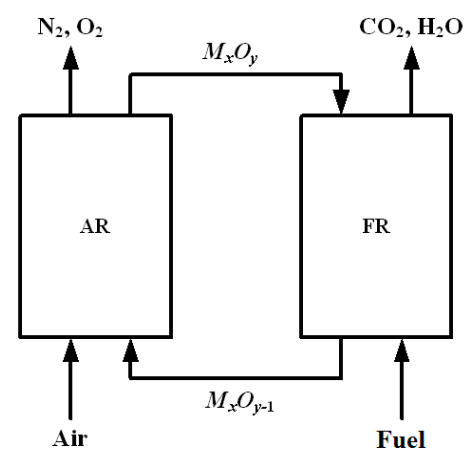

Figure 1. A schematic diagram of the chemical looping combustion (CLC) system.

However, an applicable OC usually acts as one of the key factors in the CLC system because of its vital role in transferring thermal energy and oxygen. It should possess excellent properties, including enough reactivity, high oxygen transfer capacity, low production cost, environmental friendliness, and a low tendency of fragmentation and attrition [8-10]. The main materials used as OCs are transition metal oxides, such as $\mathrm{Mn}_{3} \mathrm{O}_{4}, \mathrm{Fe}_{2} \mathrm{O}_{3}, \mathrm{NiO}, \mathrm{CuO}$, and $\mathrm{CoO}$ [11-16]. Among these metal oxides, Fe-based $\mathrm{OC}$ has been recognized as one of the most promising candidates, because it possesses the advantages of being low cost, having a good thermal stability, and being environmentally friendly [17-20]. Though Fe-based $\mathrm{OC}$ has high theoretical oxygen capacity $(30 \%)$ from $\mathrm{Fe}_{2} \mathrm{O}_{3}$ to $\mathrm{Fe}$, it has lower reactivity and oxygen transfer rate compared to Ni-based OC and $\mathrm{Cu}$-based OC during CLC process. Reduction of $\mathrm{Fe}_{2} \mathrm{O}_{3}$ experiences the process as below: $\mathrm{Fe}_{2} \mathrm{O}_{3} \rightarrow \mathrm{Fe}_{3} \mathrm{O}_{4} \rightarrow \mathrm{Fe}_{1-x} \mathrm{O} \rightarrow \mathrm{Fe}$, which shows relatively high reactivity during the first stage from $\mathrm{Fe}_{2} \mathrm{O}_{3}$ to $\mathrm{Fe}_{3} \mathrm{O}_{4}$, while further reduction into $\mathrm{FeO}$ or Fe shows lower reaction rate [21,22]. Tang et al. [23] found that the transformation from $\mathrm{Fe}_{2} \mathrm{O}_{3}$ to $\mathrm{Fe}_{3} \mathrm{O}_{4}$ was suitable for the total oxidation of $\mathrm{CH}_{4}$, while partial oxidation of $\mathrm{CH}_{4}$ is more favored during the reduced stage from $\mathrm{FeO}$ to $\mathrm{Fe}$, which implies that the reactivity of Fe-based OC depends greatly on its oxidation state.

In addition, while being used as OC, the pure metal oxides will be gradually reduced, which tend to agglomerate under high temperature in the FR, and the reduced OC is difficult to re-oxidize back to its original structure in the AR [24]. It has been proved that loading metal oxides onto inert oxide supports-especially onto $\mathrm{Al}_{2} \mathrm{O}_{3}$ - can act as a very efficient method to solve these problems $[25,26]$. Cabello et al. [27] claimed that $\mathrm{Al}_{2} \mathrm{O}_{3}$ present in the Fe-based $\mathrm{OC}$ particles promotes full combustion of fuel into $\mathrm{CO}_{2}$ and $\mathrm{H}_{2} \mathrm{O} . \mathrm{Al}_{2} \mathrm{O}_{3}$ not only influences the structure of Fe-based $\mathrm{OC}$, but also alters its chemical properties for CLC of fuel. However, the synergetic effect of $\mathrm{Al}_{2} \mathrm{O}_{3}$ on the reactivity of the prefect and reduced $\mathrm{Fe}_{2} \mathrm{O}_{3}$ during the CLC process has not been adequately revealed. In particular, the mechanisms of $\mathrm{CO}$ oxidations and catalyzed $\mathrm{CO}$ decomposition on the surface of the gradually reduced $\mathrm{Fe}_{2} \mathrm{O}_{3}$ supported on $\mathrm{Al}_{2} \mathrm{O}_{3}$ remain unknown.

To address these points, a comprehensive study based on experiments was performed to detect the influences of temperature on carbon deposition and the reactivity of the oxygen carrier $\left(\mathrm{Fe}_{2} \mathrm{O}_{3} / \mathrm{Al}_{2} \mathrm{O}_{3}\right)$ in a lab-scale fluidized bed, thermogravimetric analysis (TGA) unit. The synergetic effects of $\mathrm{Al}_{2} \mathrm{O}_{3}$ on the reactivity of the pure and reduced $\mathrm{Fe}_{2} \mathrm{O}_{3}$ for $\mathrm{CO}$ oxidations and decomposition during the $\mathrm{CLC}$ process were detected by performing density functional theory (DFT) calculations. The results may provide a deep insight into the gradually changing activity of the reduced $\mathrm{Fe}_{2} \mathrm{O}_{3} / \mathrm{Al}_{2} \mathrm{O}_{3}$ particle for $\mathrm{CO}$ adsorption, oxidation, and decomposition reactions.

\section{Experimental and Theoretical Method}

\subsection{Preparation of the Oxygen Carrier}

The properties of the oxygen carrier are largely dependent on its active components and the preparation methods [28]. A modified incipient impregnation method was used to prepare an oxygen 
carrier of $\mathrm{Fe}_{2} \mathrm{O}_{3} / \mathrm{Al}_{2} \mathrm{O}_{3}$ (the mass fraction of $\mathrm{Fe}_{2} \mathrm{O}_{3}$ is $15 \mathrm{wt} \%$ ). Stoichiometric amounts of iron nitrate precursor are dissolved in water under continuous stirring at $40{ }^{\circ} \mathrm{C}$ in order to increase the solubility of the nitrate. After the complete dissolution of nitrate, the alumina particles were slowly added to the solution. Then the mixtures were further treated by ultrasonic for $12 \mathrm{~h}$, and were dried at $110^{\circ} \mathrm{C}$ overnight. Finally, the dried samples were calcined at $550{ }^{\circ} \mathrm{C}$ for $5 \mathrm{~h}$ under oxidizing conditions, then crushed and sieved to a particle size of $0.1-0.3 \mathrm{~mm}$ for the CLC experiments.

\subsection{Combustion Experiment}

CLC experiments were conducted in a fluidized-bed reactor, where a quartz tube (with an inner diameter of $16 \mathrm{~mm}$ and a total length of $1500 \mathrm{~mm}$ ) was placed in an oven with a porous distributor plate located $550 \mathrm{~mm}$ from the bottom, and the oxygen carrier particles were placed on the porous quartz plate, as illustrated in Figure 2. Four different operating temperatures $\left(700{ }^{\circ} \mathrm{C}, 800{ }^{\circ} \mathrm{C}, 900{ }^{\circ} \mathrm{C}\right.$, and $1000^{\circ} \mathrm{C}$ ) were used, and the real-time temperature was measured at a point of $10 \mathrm{~mm}$ above the porous quartz plate with an accuracy of $\pm 2{ }^{\circ} \mathrm{C}$. A $6 \mathrm{~g}$ sample of $\mathrm{Fe}_{2} \mathrm{O}_{3} / \mathrm{Al}_{2} \mathrm{O}_{3}$ particles with a size of $0.1-0.3 \mathrm{~mm}$ was placed on the porous plate and then initially heated to the reaction temperatures in an inert atmosphere $\left(\mathrm{N}_{2}\right)$. Then, the sample was alternately exposed to $\mathrm{CO}$, and the air atmosphere was introduced into the reactor at the bottom of the tube, respectively. In order to prevent the mixing of fuel gas and air, $\mathrm{N}_{2}$ was introduced to the reactor for $180 \mathrm{~s}$ between each reducing period and oxidizing period. The gas flow of $\mathrm{N}_{2}$, air, and $\mathrm{CO}$ was $500 \mathrm{~mL} / \mathrm{min}$. The outlet gases were tested using a gas analyzer (Intelligent Analytical Instruments XLZ-1090, Sielins, Beijing, China) to record the concentration of $\mathrm{CO}_{2}$. Furthermore, the fresh and the used oxygen carriers were tested by X-ray Diffraction (XRD, D/MAX-RB, Rigaku, Tokyo, Japan), Scanning Electron Microscope (SEM, LEO-1450, Carl Zeiss AG, Oberkochen, Germany), and Brunauer-Emmett-Teller (BET, Autosorb-iQ-MP, Quantachrome, Boynton Beach, FL, USA).



Figure 2. A schematic diagram of the fluidized-bed reactor system.

\subsection{Thermal Gravimetric Analysis (TGA)}

The reactivity of $\mathrm{Fe}_{2} \mathrm{O}_{3} / \mathrm{Al}_{2} \mathrm{O}_{3}$ with $\mathrm{CO}$ was carried out in a thermo gravimetric analyzer (PerkinElmer, STA6000, Boston, MA, USA). Between 40 and $50 \mathrm{mg}$ of $\mathrm{Fe}_{2} \mathrm{O}_{3} / \mathrm{Al}_{2} \mathrm{O}_{3}$ was loaded in a platinum basket and heated up to $120^{\circ} \mathrm{C} / \mathrm{min}$ at $30{ }^{\circ} \mathrm{C} / \mathrm{min}$ and held for $10 \mathrm{~min}$ to remove the moisture in the $\mathrm{N}_{2}$ atmosphere. After weight stabilization, the sample was further heated to the desired temperature with the heating rate of $50{ }^{\circ} \mathrm{C} / \mathrm{min}$. Once the set temperature was reached, the experiment was started by exposing the sample to alternating $\mathrm{CO}$ and air atmosphere for the reduction and oxidation steps. To avoid the mixing of $\mathrm{CO}$ and air, nitrogen was introduced for $3 \mathrm{~min}$ after 
each reducing and oxidizing period. In the reducing period, $\mathrm{Fe}_{2} \mathrm{O}_{3}$ is mostly reduced to other lower oxidation states of iron oxide, such as magnetite $\left(\mathrm{Fe}_{3} \mathrm{O}_{4}\right)$ and wustite $(\mathrm{FeO})$. The degree of the oxygen carrier conversion $\left(X_{\mathrm{oc}}\right)$ in the reduction reaction is defined as:

$$
X_{\mathrm{oc}}=\left(m_{\mathrm{ox}}-m\right) /\left(m_{\mathrm{ox}}-m_{\mathrm{red}}\right)
$$

where $m$ is the instantaneous weight of the sample, $m_{\mathrm{ox}}$ is the mass of the sample at its fully oxidized state, and $m_{\text {red }}$ is the weight of the sample at its fully reduced state. The difference between $m_{\mathrm{ox}}$ and $m_{\text {red }}$ in Equation (3) is the theoretical maximum amount of oxygen that can react with the CO.

\subsection{Thermodynamic Analysis}

Thermodynamic analysis was performed by FACTSAGE 7.1 (GTT-Technologies, Herzogenrath, Germany), and was used to predict the phases and compounds that can be formed, and their fractions and thermodynamic properties at given temperatures and pressures similar to the experimental conditions employed [29]. The Gibbs free energy change $(\Delta G)$ of the reduction reaction of $\mathrm{Fe}_{2} \mathrm{O}_{3}$ was calculated to discuss its oxidizing capability with $C O . \Delta G$ is a measure of the thermodynamic driving force that motivates the reaction process. Figure 3 presents the standard Gibbs free energy changes for all possible reactions between $\mathrm{CO}$ and iron oxide of different stable phases under various temperatures. The results indicated that all of reactions are more favored at higher temperature due to more negative values of Gibbs free energy, which is similar with the tendency of reactions between iron-based oxygen carrier and $\mathrm{CH}_{4}$ in the literature in 2005 by Xin et al. [30]. The more negative the value of $\Delta G$, the more likely that the reaction towards positive will proceed. Moreover, it also confirmed that the reactions between Fe-based oxygen carrier and $\mathrm{CO}$ became more difficult with decreasing oxidation sates. Several conditions for the generation of $\mathrm{CO}_{2}$ via the reaction of iron based oxygen carrier with $\mathrm{CO}$ are as follows:

$$
\begin{gathered}
3 \mathrm{Fe}_{2} \mathrm{O}_{3}+\mathrm{CO} \rightarrow 2 \mathrm{Fe}_{3} \mathrm{O}_{4}+\mathrm{CO}_{2} \\
\mathrm{Fe}_{2} \mathrm{O}_{3}+\mathrm{CO} \rightarrow 2 \mathrm{FeO}+\mathrm{CO}_{2} \\
\mathrm{Fe}_{2} \mathrm{O}_{3}+3 \mathrm{CO} \rightarrow 2 \mathrm{Fe}+3 \mathrm{CO}_{2} \\
\mathrm{Fe}_{3} \mathrm{O}_{4}+\mathrm{CO} \rightarrow 3 \mathrm{FeO}+\mathrm{CO}_{2} \\
\mathrm{Fe}_{3} \mathrm{O}_{4}+4 \mathrm{CO} \rightarrow 3 \mathrm{Fe}+4 \mathrm{CO}_{2} \\
\mathrm{FeO}+\mathrm{CO} \rightarrow \mathrm{Fe}+\mathrm{CO}_{2}
\end{gathered}
$$

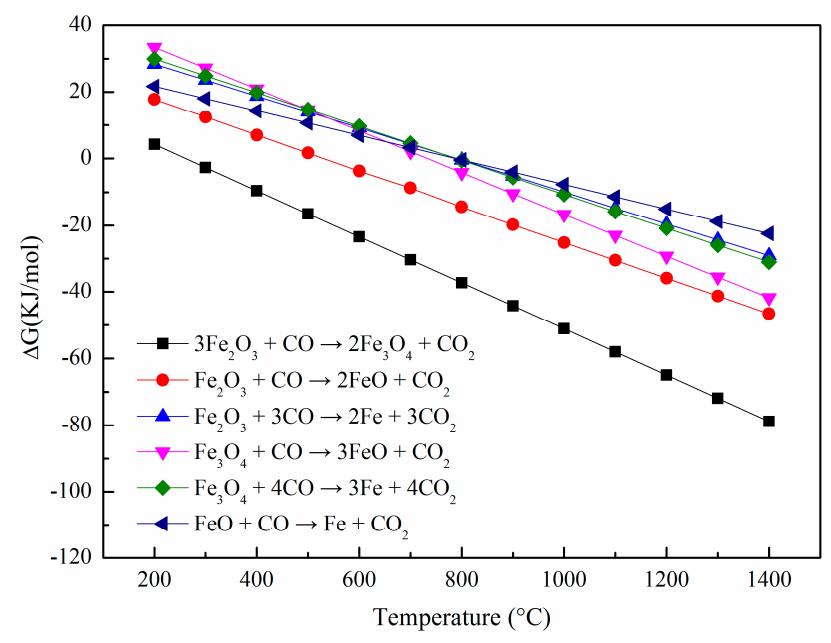

Figure 3. The variations of $\Delta G$ with the temperature for Reactions (4)-(9). 


\subsection{Theoretical Method}

$\mathrm{Fe}_{2} \mathrm{O}_{3}(001)$ is one of the dominant growth faces of the natural $\alpha-\mathrm{Fe}_{2} \mathrm{O}_{3}$; five atomic layers of $\mathrm{Fe}_{2} \mathrm{O}_{3}(001)$ were modeled and supported on four matching atomic layers of $\mathrm{Al}_{2} \mathrm{O}_{3}(001)$ to simulate the $\mathrm{Fe}_{2} \mathrm{O}_{3} / \mathrm{Al}_{2} \mathrm{O}_{3}$ system. Then, the reduced $\mathrm{Fe}_{2} \mathrm{O}_{3} / \mathrm{Al}_{2} \mathrm{O}_{3}$ was modeled by gradually removing the $\mathrm{O}$ atom on the top layer. The stable configurations of the pure and reduced $\mathrm{Fe}_{2} \mathrm{O}_{3} / \mathrm{Al}_{2} \mathrm{O}_{3}$ supported slabs are shown in Figure 4. Based on these optimized surfaces, $\mathrm{CO}$ adsorption, oxidation, and decomposition reactions were investigated.
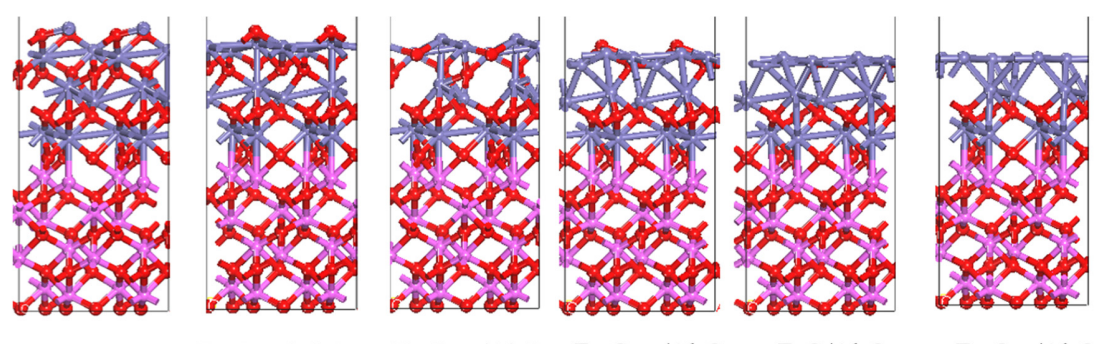

$\mathrm{Fe}_{2} \mathrm{O}_{3} / \mathrm{Al}_{2} \mathrm{O}_{3}$

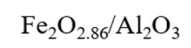

$\mathrm{Fe}_{2} \mathrm{O}_{2.57} / \mathrm{Al}_{2} \mathrm{O}_{3} \quad \mathrm{Fe}_{2} \mathrm{O}_{2.29} / \mathrm{Al}_{2} \mathrm{O}_{3}$

$\mathrm{FeO} / \mathrm{Al}_{2} \mathrm{O}_{3}$

$\mathrm{Fe}_{2} \mathrm{O}_{1.7} / \mathrm{Al}_{2} \mathrm{O}_{3}$

Figure 4. The stable configurations of the pure $\mathrm{Fe}_{2} \mathrm{O}_{3} / \mathrm{Al}_{2} \mathrm{O}_{3}$ slab and a series of the reduced $\mathrm{Fe}_{2} \mathrm{O}_{3} / \mathrm{Al}_{2} \mathrm{O}_{3}$ slabs.

All calculations were performed using DFT with the generalized gradient approximation (GGA) [31] of Perdew, Burke, and Ernzerhof (PBE) [32] to realize the exchange correlation potential [33]. The electronic wave functions were expanded in a plane-wave basis set with a cut-off energy of $350 \mathrm{eV}$ in all calculations, and the convergence criteria was set at the medium level. All reactants, products, intermediates, and transition states were completely optimized, and were confirmed to be the local minimum energy by frequency analysis. Optimization of the energy, displacement, and force convergence was used as a criterion. The convergence valves were $2.0 \times 10^{-5} \mathrm{Ha} /$ atom, $5.0 \times 10^{-3} \AA$, and $4.0 \times 10^{-3} \mathrm{Ha} / \AA$, respectively. The binding energies $\left(E_{B}\right)$ for the studied interaction systems were calculated by using the following equation:

$$
E_{B}=E(\mathrm{CO}-\mathrm{OC})-E(\mathrm{OC})-E(\mathrm{CO})
$$

where $E(\mathrm{OC})$ is the energy of the isolated oxygen carrier, $E(\mathrm{CO})$ is the energy of an isolated CO molecule, and $E(\mathrm{CO}-\mathrm{OC})$ is the total energy of the $\mathrm{CO}$ interacting with the $\mathrm{Fe}_{2} \mathrm{O}_{3}$ system under consideration. The transition state of the $\mathrm{CO}$ oxidation was searched using the complete linear/quadratic synchronous transit (LST/QST) [34,35].

\section{Results and Discussion}

\subsection{Experimental Results in the Fluidized-Bed Reactor}

Firstly, we focused on the performance of $\mathrm{Fe}_{2} \mathrm{O}_{3} / \mathrm{Al}_{2} \mathrm{O}_{3}$ for the CLC of $\mathrm{CO}$ in a fluidized bed reactor for five redox cycles. The reduction efficiency of $\mathrm{Fe}_{2} \mathrm{O}_{3} / \mathrm{Al}_{2} \mathrm{O}_{3}$ in the $\mathrm{AR}$ was characterized by analyzing the concentration of the outlet $\mathrm{CO}_{2}$. Figure 5a displays the $\mathrm{CO}_{2}$ concentration of the fifth reduction period at different reaction temperatures. Because $\mathrm{CO}$ was introduced into the $\mathrm{FR}$, the reaction between $\mathrm{Fe}_{2} \mathrm{O}_{3} / \mathrm{Al}_{2} \mathrm{O}_{3}$ and $\mathrm{CO}$ made the concentration of $\mathrm{CO}_{2}$ rapidly increase and reach $100 \%$ at $700{ }^{\circ} \mathrm{C}, 800{ }^{\circ} \mathrm{C}$, and $900{ }^{\circ} \mathrm{C}$. Then the concentration of $\mathrm{CO}_{2}$ declined quickly after the $\mathrm{Fe}_{2} \mathrm{O}_{3} / \mathrm{Al}_{2} \mathrm{O}_{3}$ was reduced to a certain oxidation state, as the oxygen in the $\mathrm{Fe}_{2} \mathrm{O}_{3} / \mathrm{Al}_{2} \mathrm{O}_{3}$ particle was gradually depleted with the CLC process. The results indicated that the oxygen carrier has a high reactivity and can fully oxidize $\mathrm{CO}$ into $\mathrm{CO}_{2}$ at a certain reduction period, and that pure $\mathrm{CO}_{2}$ could be captured by controlling the reaction time of the oxygen carrier in the FR. However, the concentration of $\mathrm{CO}_{2}$ only reached $80 \%$ at $1000{ }^{\circ} \mathrm{C}$, which may be attributed to the agglomeration of the oxygen 
carrier and the occurrence of less oxygen transfer during the reduction period, because less carbon deposition happened in this case in comparison with the other cases.
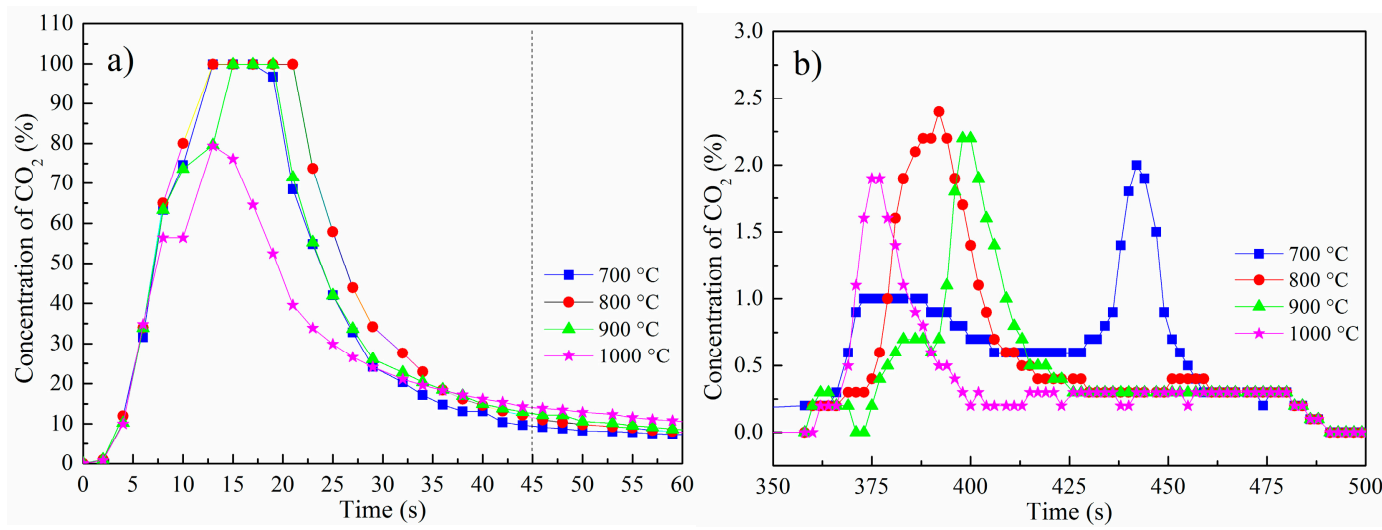

Figure 5. $\mathrm{CO}_{2}$ concentration for (a) the reduction reaction process between $\mathrm{Fe}_{2} \mathrm{O}_{3} / \mathrm{Al}_{2} \mathrm{O}_{3}$ and $\mathrm{CO}$ in the FR and (b) the regeneration reaction process between the reduced $\mathrm{Fe}_{2} \mathrm{O}_{3} / \mathrm{Al}_{2} \mathrm{O}_{3}$ and air in the $\mathrm{AR}$, under various temperatures.

Except for the reduction efficiency, carbon deposition on the reduced $\mathrm{Fe}_{2} \mathrm{O}_{3} / \mathrm{Al}_{2} \mathrm{O}_{3}$ is another important factor to characterize the behavior of the prepared $\mathrm{Fe}_{2} \mathrm{O}_{3} / \mathrm{Al}_{2} \mathrm{O}_{3}$. If carbon deposits on the reduced $\mathrm{Fe}_{2} \mathrm{O}_{3} / \mathrm{Al}_{2} \mathrm{O}_{3}$, carbon will be brought into the $\mathrm{AR}$, leading to the generation of $\mathrm{CO}_{2}$ in the oxidation period [36]. Figure $5 \mathrm{~b}$ shows the $\mathrm{CO}_{2}$ concentration for the fifth oxidation period in the AR under different temperatures. As can be seen in Figure 5b, the most obvious carbon deposition happens for the case at $700{ }^{\circ} \mathrm{C}$, corresponding to the report that low temperature favors carbon deposition due to the Boudouard reaction of $\mathrm{CO}$ during the $\mathrm{CO}$ CLC process [37].

We further calculated the conversion of $\mathrm{Fe}_{2} \mathrm{O}_{3} / \mathrm{Al}_{2} \mathrm{O}_{3}$ through the yield of $\mathrm{CO}_{2}$, which can be measured by the concentration of $\mathrm{CO}_{2}$ and the rate of $\mathrm{CO}$ flow inlet into the reactor. The results indicate that the conversions of oxygen carrier are $0.503,0.571,0.514$, and 0.322 at $700{ }^{\circ} \mathrm{C}, 800{ }^{\circ} \mathrm{C}$, $900{ }^{\circ} \mathrm{C}$, and $1000^{\circ} \mathrm{C}$ within the period of 0 to $44 \mathrm{~s}$ (as displayed in Figure 5a), which means that a large number of $\mathrm{Fe}_{2} \mathrm{O}_{3}$ was reduced to $\mathrm{FeO}$ and $\mathrm{Fe}$.

In order to analyze the carbon conversion and the amount of carbon deposition, the relative fraction $\left(f_{i}\right)$ of $\mathrm{CO}$ and $\mathrm{CO}_{2}$ in the outlet gases were calculated using the following equation [38]:

$$
f_{i}=\frac{\int_{0}^{t} n_{\text {out }} x_{i} \mathrm{dt}}{\int_{0}^{t} n_{\text {out }}\left(x_{\mathrm{CO}}+x_{\mathrm{CO}_{2}}\right) \mathrm{dt}}
$$

where $x_{i}$ is the molar fraction of $i$ indicated by the subscript in the outlet gases during the reduction period, $n_{\text {out }}$ is molar flow rate of the outlet gases, and $t$ is the reaction time. The carbon dioxide yield $\left(\gamma_{\mathrm{CO}_{2}}\right)$ was used to quantify the conversion from $\mathrm{CO}$ into $\mathrm{CO}_{2}$, which was calculated using the following equation:

$$
\gamma_{\mathrm{CO}_{2}}=\frac{f_{\mathrm{CO}_{2}}}{f_{\mathrm{CO}}+f_{\mathrm{CO}_{2}}}
$$

where $\gamma_{\mathrm{CO}_{2}}=1$ denotes that all $\mathrm{CO}$ was completely converted into $\mathrm{CO}_{2}$.

Figure 6a shows the yield of $\mathrm{CO}_{2}$ as a function of temperature, where $\gamma_{\mathrm{CO}_{2}}$ first increased and then declined with the increase of temperature, and the maximum value was obtained at $800{ }^{\circ} \mathrm{C}$. This result indicates that the oxygen carrier has the highest reactivity to oxidize $\mathrm{CO}$ into $\mathrm{CO}_{2}$ at a temperature of around $800{ }^{\circ} \mathrm{C}$. This trend means that there is an equilibrium selection between the favorable carbon deposition under relatively lower temperatures $\left(<800^{\circ} \mathrm{C}\right)$ and the agglomeration of the oxygen carrier at relatively higher temperatures $\left(>800^{\circ} \mathrm{C}\right)$. Figure $6 \mathrm{~b}$ shows a decrease in the average amounts of carbon deposition with a temperature increase from $700{ }^{\circ} \mathrm{C}$ to $1000{ }^{\circ} \mathrm{C}$, corresponding to the fact that 
low temperature favors reactions for reducing CO into C [39,40]. Although carbon formation occurred in the reduction period, the total amount of carbon deposited on the oxygen carrier was not more than $3 \%$ of the mole ratio of $\mathrm{CO}$ that is used in each experiment.
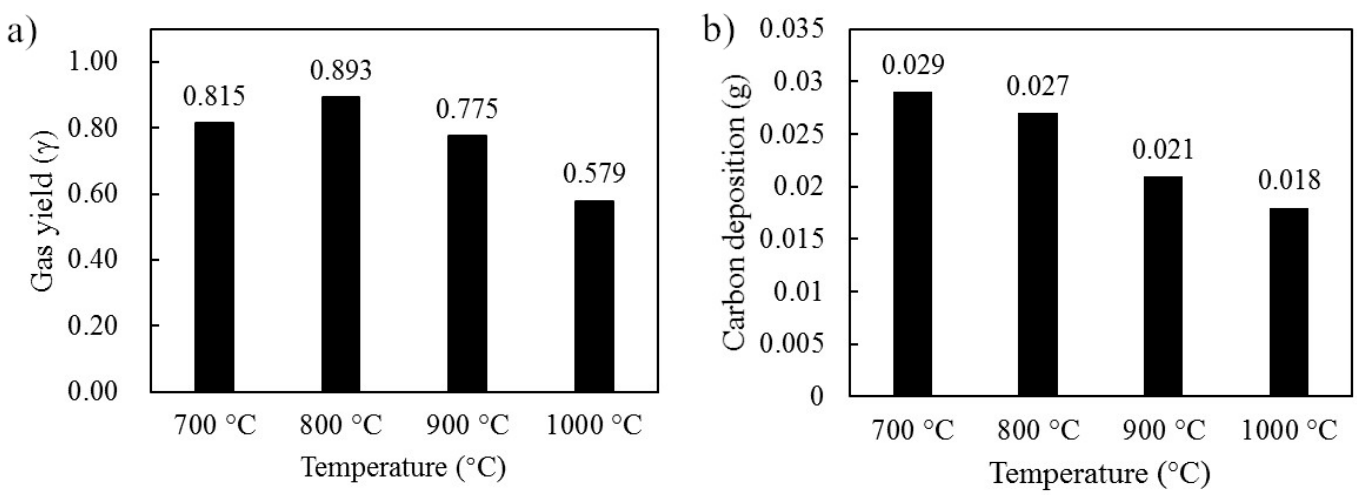

Figure 6. (a) The $\mathrm{CO}_{2}$ yield $\left(\gamma_{\mathrm{CO}_{2}}\right)$ as a function of temperature for the fifth reaction cycle and (b) the average amount of carbon deposition as a function of temperature for the five cycles.

Further, long-term experiments were carried out to investigate the thermal stability of $\mathrm{Fe}_{2} \mathrm{O}_{3} / \mathrm{Al}_{2} \mathrm{O}_{3}$ under the temperature of $800{ }^{\circ} \mathrm{C}$. After 30 reducing/oxidizing reaction cycles, the $\mathrm{CO}_{2}$ concentration could still reach $100 \%$ and keep for seconds, which confirmed that the $\mathrm{Fe}_{2} \mathrm{O}_{3} / \mathrm{Al}_{2} \mathrm{O}_{3}$ has a good reactivity and stability for $\mathrm{CO}$ oxidation, as shown in Figure $7 \mathrm{a}$. Figure $\mathrm{7b}$ shows that carbon deposition increased slightly with reaction cycles, which implies that part of the active components had been deactivated. Generally, carbon conversion at $800^{\circ} \mathrm{C}$ in long-term experiments still keeps a relatively high value, suggesting that $\mathrm{Fe}_{2} \mathrm{O}_{3} / \mathrm{Al}_{2} \mathrm{O}_{3}$ is suitable as an oxygen carrier for the CLC system.
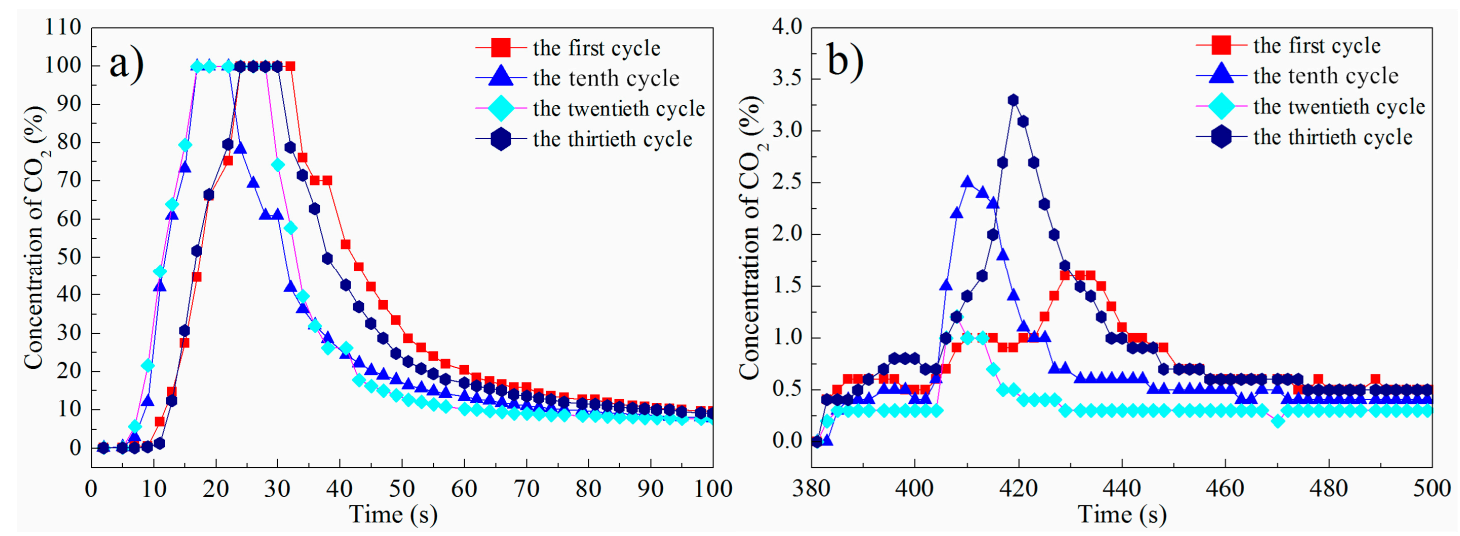

Figure 7. $\mathrm{CO}_{2}$ concentration in the outlet gas for different reaction cycles for (a) the reducing process and (b) the oxidizing process.

\subsection{TGA Experiments}

Moreover, the detailed behavior of the prepared $\mathrm{Fe}_{2} \mathrm{O}_{3} / \mathrm{Al}_{2} \mathrm{O}_{3}$ particle was detected in the TGA apparatus at different reaction temperatures $\left(700^{\circ} \mathrm{C}, 800^{\circ} \mathrm{C}, 900^{\circ} \mathrm{C}\right.$, and $\left.1000^{\circ} \mathrm{C}\right)$. During the $\mathrm{CLC}$ process, in an ideal case, the active component of $\mathrm{Fe}_{2} \mathrm{O}_{3}$ could be reduced by $\mathrm{CO}$ to different final oxidation states, such as $\mathrm{Fe}_{3} \mathrm{O}_{4}, \mathrm{FeO}$, and $\mathrm{Fe}$, with the corresponding conversion $\chi$ of $0.11,0.33$, and 1 , respectively. Figure 8 compares the TGA results under four different temperatures, where the $\mathrm{Fe}_{2} \mathrm{O}_{3} / \mathrm{Al}_{2} \mathrm{O}_{3}$ particle shows the highest conversation at $800{ }^{\circ} \mathrm{C}$ and the lowest at $1000{ }^{\circ} \mathrm{C}$ due to the agglomeration under high temperature reported by Bao et al. [41]. The TGA result corresponds to that of the fluidized-bed experiments. Moreover, all the conversation curves suggest that the reduction of 
$\mathrm{Fe}_{2} \mathrm{O}_{3} / \mathrm{Al}_{2} \mathrm{O}_{3}$ under various temperatures experienced three distinct reaction stages. The first stage is for the reduction of $\mathrm{Fe}_{2} \mathrm{O}_{3}$ into the oxidation state between $\mathrm{Fe}_{3} \mathrm{O}_{4}$ and $\mathrm{FeO}$ with the highest reaction rate and shortest time occupied. The second stage is for further reduction into another oxidation state lower than $\mathrm{FeO}$ with a lower reaction rate. Finally, the third stage is for deeper reduction of the OC, but where the OC was not completely reduced into Fe. The same results were likewise obtained from our previous work [42]. In short, deeper reduction degrees show lower reactivity. In addition, the reaction between $\mathrm{Fe}_{2} \mathrm{O}_{3} / \mathrm{Al}_{2} \mathrm{O}_{3}$ and $\mathrm{CO}$ shows the highest efficiency under $800{ }^{\circ} \mathrm{C}$.



Figure 8. Conversion $\chi$ as a function of reaction time for the fifth reduction period at $700{ }^{\circ} \mathrm{C}, 800{ }^{\circ} \mathrm{C}$, $900{ }^{\circ} \mathrm{C}$, and $1000^{\circ} \mathrm{C}$.

Further, temperature-programming TGA experiments were performed to investigate the influence of different $\mathrm{CO}$ concentrations and $\mathrm{CO} / \mathrm{CO}_{2}$ concentrations on the equilibrium of the reaction between $\mathrm{CO}$ and the OC during CLC processes. Figure $9 \mathrm{a}$ illustrates the results of a temperature-programming TGA investigation into the reaction between $\mathrm{Fe}_{2} \mathrm{O}_{3} / \mathrm{Al}_{2} \mathrm{O}_{3}$ and $\mathrm{CO}$ at different concentrations (and different $\mathrm{CO} / \mathrm{CO}_{2}$ concentrations). With temperature increases from ambient temperature to $900{ }^{\circ} \mathrm{C}$, the CLC reaction between the $\mathrm{OC}$ and the $\mathrm{CO}$ under the conditions of different $\mathrm{CO}$ concentrations and different $\mathrm{CO} / \mathrm{CO}_{2}$ concentrations experiences two stages. The first stage corresponds to weight loss, since $\mathrm{Fe}_{2} \mathrm{O}_{3}$ was reduced by $\mathrm{CO}$ gradually with the formation of $\mathrm{CO}_{2}$. After $\mathrm{Fe}_{2} \mathrm{O}_{3}$ was reduced to a certain reduction state, more Fe atoms appeared on the surface of the reduced $\mathrm{Fe}_{2} \mathrm{O}_{3}$, which could act as active sites to catalyze the decomposition of $\mathrm{CO}$, resulting in carbon deposition on the surface showing a weight increase as the second stage. As could be seen in Figure 9, relatively lower $\mathrm{CO}$ concentration favors the reduction of $\mathrm{Fe}_{2} \mathrm{O}_{3}$, while higher $\mathrm{CO}$ concentration leads to more obvious weight increase at the second stage, where more carbon deposition happens on the surface of the reduced $\mathrm{Fe}_{2} \mathrm{O}_{3}$, leading to obvious weight increase. These results can be attributed to a higher concentration of $\mathrm{CO}$ resulting in quicker consumption of $\mathrm{O}$ atoms on the surface of $\mathrm{Fe}_{2} \mathrm{O}_{3} / \mathrm{Al}_{2} \mathrm{O}_{3}$, then more Fe atoms exposed on the surface promoting the catalytic decomposition of $\mathrm{CO}$, resulting in carbon deposition on the surface. Figure $9 \mathrm{~b}$ shows that a reasonable $\mathrm{CO} / \mathrm{CO}_{2}$ ratio favors the conversion of $\mathrm{Fe}_{2} \mathrm{O}_{3} / \mathrm{Al}_{2} \mathrm{O}_{3}$ with less carbon decomposition.

\subsection{Characterization of the Oxygen Carrier}

The BET test of the freshly prepared $\mathrm{Fe}_{2} \mathrm{O}_{3} / \mathrm{Al}_{2} \mathrm{O}_{3}$ particle shows a high specific surface area $\left(192.75 \mathrm{~m}^{2} / \mathrm{g}\right)$ compared to other oxygen carriers in previous studies [43,44]. However, the specific surface area decreases to $113.76 \mathrm{~m}^{2} / \mathrm{g}, 96.68 \mathrm{~m}^{2} / \mathrm{g}, 76.35 \mathrm{~m}^{2} / \mathrm{g}$, and $40.71 \mathrm{~m}^{2} / \mathrm{g}$ after use in a fluidized bed for five cycles at $700{ }^{\circ} \mathrm{C}, 800{ }^{\circ} \mathrm{C}, 900{ }^{\circ} \mathrm{C}$, and $1000{ }^{\circ} \mathrm{C}$, respectively. These results correspond very well to the analysis above that suggests that changes in the oxygen carrier reactivity and the $\mathrm{CO}_{2}$ yield occur when the temperature increases. 

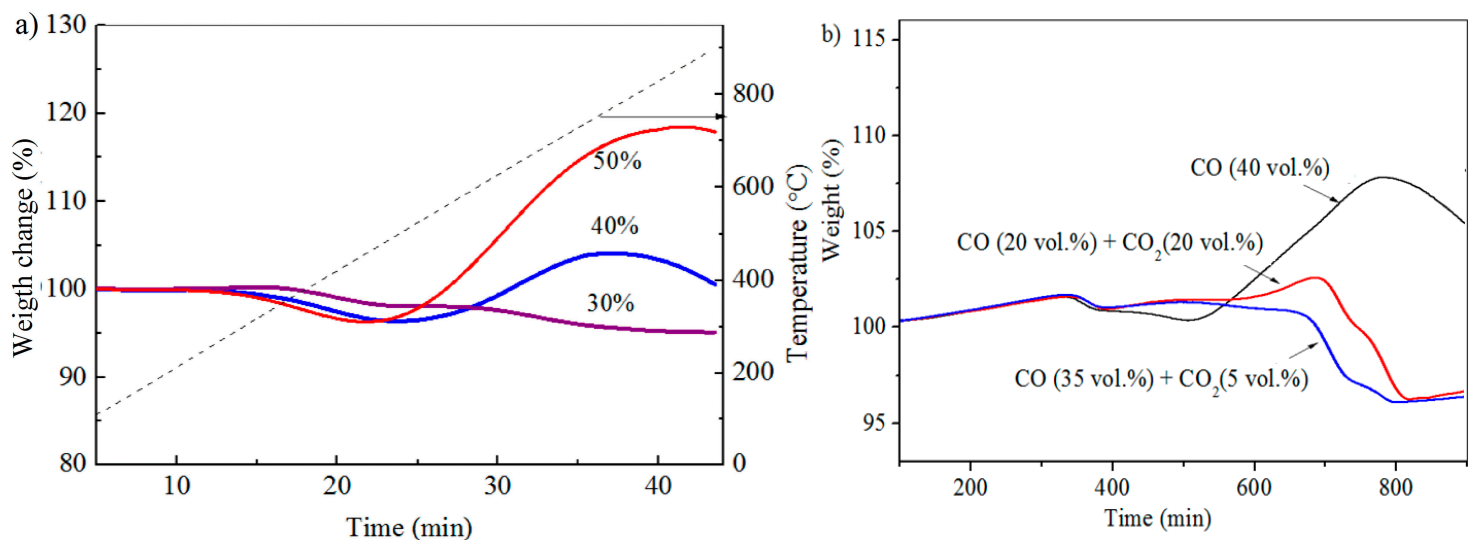

Figure 9. Thermogravimetric analysis (TGA) data for reactions at different (a) $\mathrm{CO}$ concentrations and (b) $\mathrm{CO} / \mathrm{CO}_{2}$ concentrations.

Figure 10 presents the $X R D$ patterns for the fresh $\mathrm{Fe}_{2} \mathrm{O}_{3} / \mathrm{Al}_{2} \mathrm{O}_{3}$ and the used $\mathrm{Fe}_{2} \mathrm{O}_{3} / \mathrm{Al}_{2} \mathrm{O}_{3}$ after five redox reaction cycles in the fluidized bed reactor. As can be seen, the reflections of $\mathrm{Fe}_{2} \mathrm{O}_{3}$ and $\mathrm{Al}_{2} \mathrm{O}_{3}$ in the fresh oxygen carrier are weak and broad. Both the characteristic peaks of the oxygen carrier became intensified and narrow after reacting with $\mathrm{CO}$ in the fluidized bed reactor. This illustrates that the lattice size of the crystals in the oxygen carrier was increased. Further, the characteristic peaks of $\mathrm{Fe}_{3} \mathrm{O}_{4}$ and $\mathrm{FeO}$ were detected in the used oxygen carriers, which indicated that most of the $\mathrm{Fe}_{2} \mathrm{O}_{3}$ was reduced to $\mathrm{FeO}$ and $\mathrm{Fe}_{3} \mathrm{O}_{4}$. In addition, the $\mathrm{FeAl}_{2} \mathrm{O}_{4}$ was also detected in XRD patterns. Hafizi et al. [45] also found that $\mathrm{FeAl}_{2} \mathrm{O}_{4}$ was generated in their oxygen carrier of $\mathrm{Fe} / \mathrm{Ca} / \mathrm{Al}_{2} \mathrm{O}_{3}$ prepared by the sequential impregnation method. Therefore, this irreversible reaction between active components and inert carriers is one of the problems that needs to be addressed during the CLC process [44].



Figure 10. $\mathrm{XRD}$ patterns for the fresh $\mathrm{Fe}_{2} \mathrm{O}_{3} / \mathrm{Al}_{2} \mathrm{O}_{3}$ and the used $\mathrm{Fe}_{2} \mathrm{O}_{3} / \mathrm{Al}_{2} \mathrm{O}_{3}$ after five redox reaction cycles under various temperatures. 
The morphologies of the fresh $\mathrm{Fe}_{2} \mathrm{O}_{3} / \mathrm{Al}_{2} \mathrm{O}_{3}$ and the used $\mathrm{Fe}_{2} \mathrm{O}_{3} / \mathrm{Al}_{2} \mathrm{O}_{3}$ after 5 and 30 oxidation-reduction cycles under $800{ }^{\circ} \mathrm{C}$ in a fluidized-bed reactor were analyzed using SEM, as shown in Figure 11. In Figure 11a, the image of the fresh $\mathrm{Fe}_{2} \mathrm{O}_{3} / \mathrm{Al}_{2} \mathrm{O}_{3}$ has a dense surface and the grains are regular. However, the images of the used $\mathrm{Fe}_{2} \mathrm{O}_{3} / \mathrm{Al}_{2} \mathrm{O}_{3}$ for the 5th and 30th cycles had many morphological changes, which became coarser and more porous, as shown in Figure 11b,c. The SEM images indicate that the oxygen carrier had not agglomerated in any obvious way after 30 cycles.
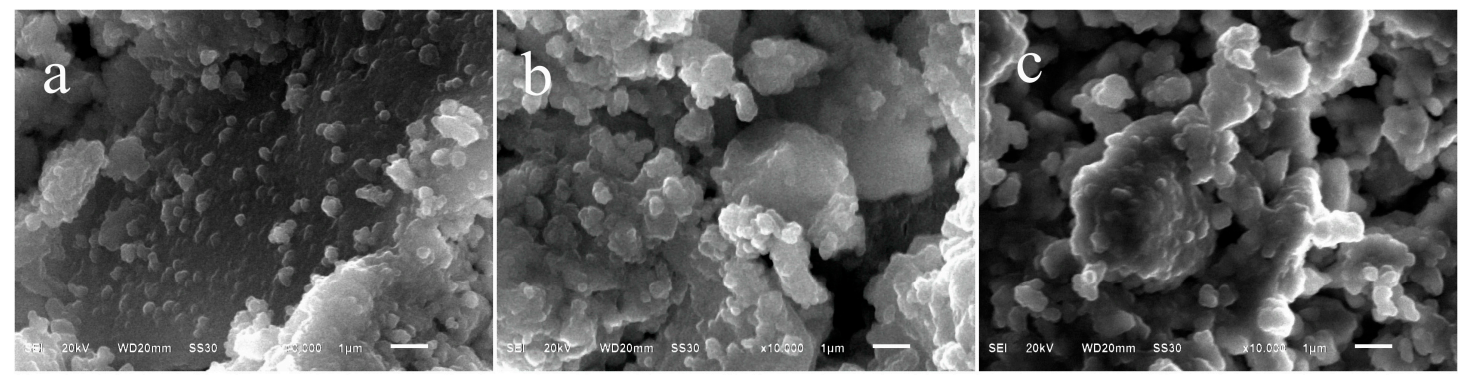

Figure 11. (a) SEM images of the fresh oxygen carrier; (b) the oxygen carrier used after five reducing/oxidizing cycles at $800{ }^{\circ} \mathrm{C}$; and (c) the oxygen carrier after 30 reducing/oxidizing cycles at $800{ }^{\circ} \mathrm{C}$.

\subsection{The Mechanism of $\mathrm{CO} C L C$ on $\mathrm{Fe}_{2} \mathrm{O}_{3} / \mathrm{Al}_{2} \mathrm{O}_{3}$}

Further, the internal association between the reactivity and the gradually changed structure (and property) of the reduced $\mathrm{Fe}_{2} \mathrm{O}_{3} / \mathrm{Al}_{2} \mathrm{O}_{3}$, as well as the synergetic effect of $\mathrm{Al}_{2} \mathrm{O}_{3}$ on the active component (the pure and the reduced $\mathrm{Fe}_{2} \mathrm{O}_{3}$ ) were discussed by investigating the electronic property of the $\mathrm{Fe}_{2} \mathrm{O}_{3} / \mathrm{Al}_{2} \mathrm{O}_{3}$ layer structure, and the mechanisms of adsorption, oxidation, and decomposition of $\mathrm{CO}$ on the pure $\mathrm{Fe}_{2} \mathrm{O}_{3} / \mathrm{Al}_{2} \mathrm{O}_{3}$ and the reduced $\mathrm{Fe}_{2} \mathrm{O}_{3} / \mathrm{Al}_{2} \mathrm{O}_{3}$ particle.

Figure 12 depicts the electron density difference for the stable $\mathrm{Fe}_{2} \mathrm{O}_{3} / \mathrm{Al}_{2} \mathrm{O}_{3}$ slab. According to Figures 4 and 12, it can be observed that a hybrid occurs at the interface between $\mathrm{Fe}_{2} \mathrm{O}_{3}$ and $\mathrm{Al}_{2} \mathrm{O}_{3}$, leading to a longer Fe-O bond (an average value of $0.211 \mathrm{~nm}$ ) at the interface than that in the bulk phase (an average value of $0.202 \mathrm{~nm}$ ), and the newly formed Al-O bond at the interface is of $0.194 \mathrm{~nm}$, slightly shorter than the bulk Al-O bond $(0.191 \mathrm{~nm})$. The newly formed Al-O shows a symmetric electron density different from that of the $\mathrm{Al}-\mathrm{O}$ of the $\mathrm{Al}_{2} \mathrm{O}_{3}$ slab, showing an obvious electronic interaction at the interface. Figure $12 \mathrm{~b}$ depicts the total density of state (DOS) for the $\mathrm{O}$ atom on the bottom layer of $\mathrm{Fe}_{2} \mathrm{O}_{3}$, as well as that for the $\mathrm{O}$ and $\mathrm{Al}$ atoms on the top layer of $\mathrm{Al}_{2} \mathrm{O}_{3}$, which shows an obvious energy overlap between the $\mathrm{O}$ atom on the bottom layer of $\mathrm{Fe}_{2} \mathrm{O}_{3}$ and the $\mathrm{Al}$ atom on the top layer of $\mathrm{Al}_{2} \mathrm{O}_{3}$, leading to a strong hybrid. The electron population around the $\mathrm{O}$ atom on the bottom layer of $\mathrm{Fe}_{2} \mathrm{O}_{3}$ is similar to that of the $\mathrm{O}$ atom on the top layer of $\mathrm{Al}_{2} \mathrm{O}_{3}$. This result confirms the stability of such supported $\mathrm{Fe}_{2} \mathrm{O}_{3} / \mathrm{Al}_{2} \mathrm{O}_{3}$ systems and the formation of $\mathrm{FeAl}_{2} \mathrm{O}_{4}$ species analyzed above by XRD.

Based on the stable $\mathrm{Fe}_{2} \mathrm{O}_{3} / \mathrm{Al}_{2} \mathrm{O}_{3}$, we want to go deeper into the mechanisms of adsorption, oxidation, and decomposition of $\mathrm{CO}$ during CLC. Because $\mathrm{CO}$ prefers to interact with the Fe atom of $\mathrm{Fe}_{2} \mathrm{O}_{3}$ through the $\mathrm{C}$ atom [37], the interaction between $\mathrm{CO}$ and the $\alpha-\mathrm{Fe}_{2} \mathrm{O}_{3}(001)$ surface was done by approaching the $\mathrm{CO}$ molecule to the Fe atom to do geometric optimization. Then, the adsorption energy was calculated according to Equation (10). Figure 11 compares the adsorption energy of $\mathrm{CO}$ on the pure and reduced $\mathrm{Fe}_{2} \mathrm{O}_{3} / \mathrm{Al}_{2} \mathrm{O}_{3}$ (seen in Figure 4), in comparison with the adsorption energy of $\mathrm{CO}$ on the pure and reduced $\mathrm{Fe}_{2} \mathrm{O}_{3}$ in our previous work [46]. The support that $\mathrm{Al}_{2} \mathrm{O}_{3}$ promotes in the interaction between $\mathrm{CO}$ and the surfaces can be observed in Figure 13, with the adsorption energy of $-1.51 \mathrm{eV},-1.61 \mathrm{eV},-1.97 \mathrm{eV},-2.13 \mathrm{eV},-2.16 \mathrm{eV}$, and $-2.25 \mathrm{eV}$ for the $\mathrm{CO}-\mathrm{Fe}_{2} \mathrm{O}_{3} / \mathrm{Al}_{2} \mathrm{O}_{3}, \mathrm{CO}-\mathrm{Fe}_{2} \mathrm{O}_{2.86} / \mathrm{Al}_{2} \mathrm{O}_{3}, \mathrm{CO}-\mathrm{Fe}_{2} \mathrm{O}_{2.57} / \mathrm{Al}_{2} \mathrm{O}_{3}, \mathrm{CO}-\mathrm{Fe}_{2} \mathrm{O}_{2.29} / \mathrm{Al}_{2} \mathrm{O}_{3}, \mathrm{CO}-\mathrm{Fe}_{2} \mathrm{O}_{2} / \mathrm{Al}_{2} \mathrm{O}_{3}$, and $\mathrm{CO}-\mathrm{Fe}_{2} \mathrm{O}_{1.7} / \mathrm{Al}_{2} \mathrm{O}_{3}$ systems, respectively. Generally, deeper reduction shows stronger interaction, which corresponds to the case between $\mathrm{CO}$ and the surface without the support [46]. 
a)

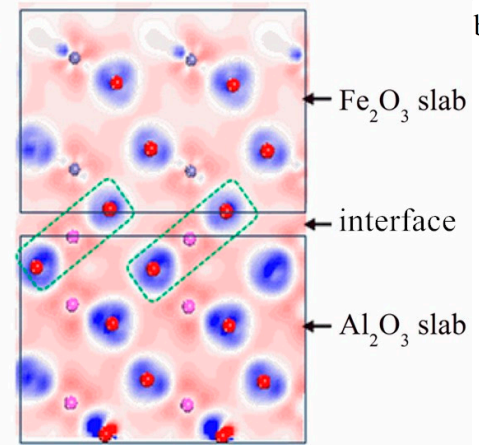

b)



Figure 12. (a) The electron density difference in the isosurface (0.1) of the $\mathrm{Fe}_{2} \mathrm{O}_{3} / \mathrm{Al}_{2} \mathrm{O}_{3}$ slab and (b) the total density of state (DOS) for the $\mathrm{O}$ atom on the bottom layer of $\mathrm{Fe}_{2} \mathrm{O}_{3}$, as well as that for the $\mathrm{O}$ and $\mathrm{Al}$ atom on the top layer of $\mathrm{Al}_{2} \mathrm{O}_{3}$.

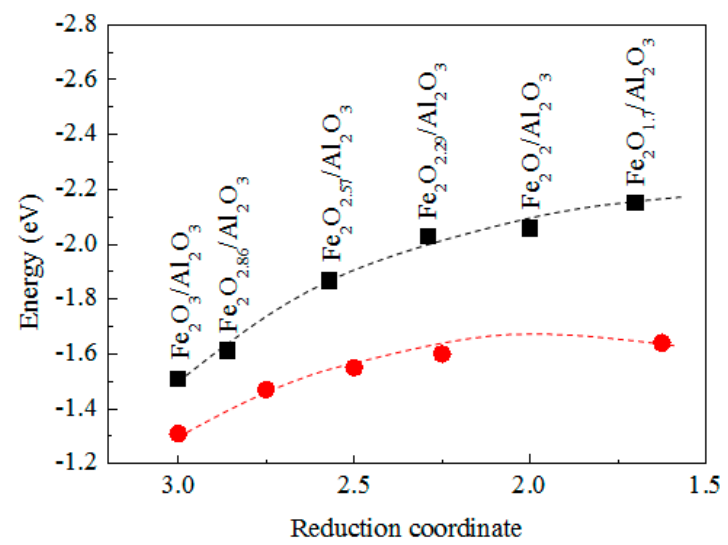

Figure 13. The adsorption energy of $\mathrm{CO}$ on the pure and reduced $\mathrm{Fe}_{2} \mathrm{O}_{3} / \mathrm{Al}_{2} \mathrm{O}$.

After the adsorption of $\mathrm{CO}$ on the $\mathrm{OC}$ surface, $\mathrm{CO}$ reacts to lattice oxygen on the surface, breaking $\mathrm{O}-\mathrm{Fe}$ bonds and forming oxygen vacancy, and thus leading to the gradually reduced process of $\mathrm{Fe}_{2} \mathrm{O}_{3} / \mathrm{Al}_{2} \mathrm{O}_{3}$. Therefore, the corresponding oxygen vacancy formation energy $\left(E_{\text {vac }}\right)$ could be used to characterize the reduction in the reactivity of the surface. The $E_{v a c}$ was calculated using the following equation:

$$
E_{\text {vac }}=\frac{E_{\mathrm{O}_{2}}}{2}+E_{\text {slab }, r}^{k-1}-E_{\text {slab,r }}^{k}
$$

where $k$ refers to the number of $\mathrm{O}$ atoms, $E_{\text {slab, } r}$ is the total energy of the optimized slab, and $E_{\mathrm{O}_{2}}$ is the total energy of the $\mathrm{O}_{2}$ molecule. $E_{v a c}$ is the obtained energy for the $\mathrm{O}$ vacancy formation.

Figure 14 illustrates the energy profiles between $E_{v a c}$ and the theoretical valence of the Fe atom of the pure and reduced $\mathrm{Fe}_{2} \mathrm{O}_{3} / \mathrm{Al}_{2} \mathrm{O}_{3}$, in comparison with those for the pure and reduced $\mathrm{Fe}_{2} \mathrm{O}_{3}(001)$ with the supported $\mathrm{Al}_{2} \mathrm{O}_{3}$ [47] range from $3.25 \mathrm{eV}$ to $3.61 \mathrm{eV}$. However, $E_{\text {vac }}$ from the pure and reduced $\mathrm{Fe}_{2} \mathrm{O}_{3} / \mathrm{Al}_{2} \mathrm{O}_{3}$ into the $\mathrm{Fe}_{2} \mathrm{O}_{2} / \mathrm{Al}_{2} \mathrm{O}_{3}$ range is between $2.86 \mathrm{eV}$ to $3.30 \mathrm{eV}$, which is lower than those on the un-supported surfaces, respectively. The results suggest that $\mathrm{Al}_{2} \mathrm{O}_{3}$ has a synergetic effect in improving the oxygen transfer capacity from the bulk of the iron-based oxygen to the surface during the CLC of CO. The improvement in the reduction property of iron-based oxygen is due to the hybrid between $\mathrm{O}$ and $\mathrm{Al}$ at the interface.

As the experimental analysis results and our previous works [48,49] show, after the reduction of $\mathrm{Fe}_{2} \mathrm{O}_{3}$ into the lower oxidation state around $\mathrm{FeO}$, a more metallic $\mathrm{Fe}$ atomic site appears on the surface, which can act as an active site for catalyzed $\mathrm{CO}$ decomposition. Herein, we compared the catalytic $\mathrm{CO}$ decomposition by $\mathrm{Fe}_{2} \mathrm{O}_{2} / \mathrm{Al}_{2} \mathrm{O}_{3}$ and $\mathrm{Fe}_{2} \mathrm{O}_{1.7} / \mathrm{Al}_{2} \mathrm{O}_{3}$, which is compared to the catalytic $\mathrm{CO}$ decomposition by $\mathrm{Fe}_{2} \mathrm{O}_{2}$ and $\mathrm{Fe}_{2} \mathrm{O}_{1.7}$. The reactions initiated from the stable adsorption of $\mathrm{CO}$ on 
the surface of the OCs, and the stable decomposition structure of $\mathrm{CO}$ on the surface of the $\mathrm{OC}$ was set as the final state. The results indicate that the decompositions of $\mathrm{CO}$ catalyzed by $\mathrm{Fe}_{2} \mathrm{O}_{2} / \mathrm{Al}_{2} \mathrm{O}_{3}$ and $\mathrm{Fe}_{2} \mathrm{O}_{1.7} / \mathrm{Al}_{2} \mathrm{O}_{3}$ pass through transition states with an energy barrier $\left(E_{a}\right)$ of $3.89 \mathrm{eV}$ and $3.16 \mathrm{eV}$, respectively. Analogously, $\mathrm{CO}$ decomposition on $\mathrm{Fe}_{2} \mathrm{O}_{2}$ and $\mathrm{Fe}_{2} \mathrm{O}_{1.7}$ had to pass through transition states with an $E_{a}$ of $4.27 \mathrm{eV}$ and $3.38 \mathrm{eV}$, respectively. These results imply that the carbon deposition rate increases with the reduction of the $\mathrm{OC}$, but no evidence could verify that $\mathrm{Al}_{2} \mathrm{O}_{3}$ favors the prevention of carbon deposition on the reduced $\mathrm{Fe}_{2} \mathrm{O}_{3} / \mathrm{Al}_{2} \mathrm{O}_{3}$.

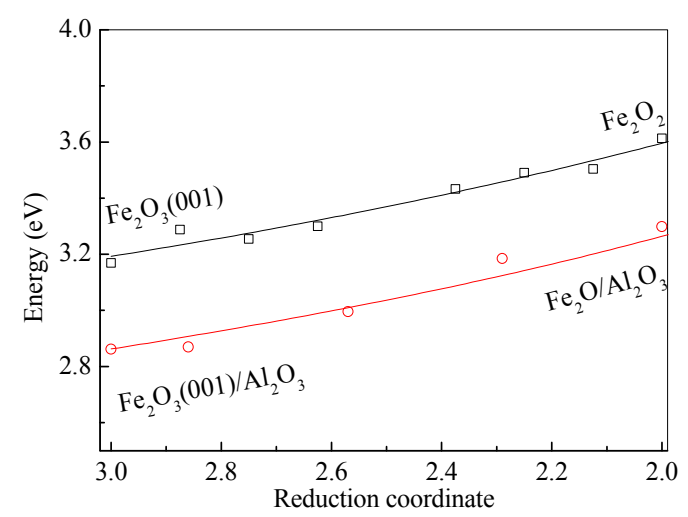

Figure 14. Energy required for removing $\mathrm{O}$ from the pure and reduced $\mathrm{Fe}_{2} \mathrm{O}_{3} / \mathrm{Al}_{2} \mathrm{O}_{3}$ gradually into $\mathrm{FeO} / \mathrm{Al}_{2} \mathrm{O}_{3}$, and $\mathrm{Fe}_{2} \mathrm{O}_{3}(001)$ into $\mathrm{FeO}$.

\section{Conclusions}

The reactivity, thermal stability, redox properties, and structural evolution of $\mathrm{Fe}_{2} \mathrm{O}_{3} / \mathrm{Al}_{2} \mathrm{O}_{3}$ were investigated in detail by multicycle tests in a fluidized bed and thermogravimetric analyzer at different reaction temperatures ranging from 700 to $1000{ }^{\circ} \mathrm{C}$. The carbon deposition occurred during the reduction period and showed a declined tendency with increasing temperature. However, the oxygen carrier showed a high reactivity and did not show an obvious decrease even after 30 cycles at $800{ }^{\circ} \mathrm{C}$. Temperature-programming TGA experiments suggested that a reasonable $\mathrm{CO} / \mathrm{CO}_{2}$ ratio favors the conversion of $\mathrm{Fe}_{2} \mathrm{O}_{3} / \mathrm{Al}_{2} \mathrm{O}_{3}$, thus avoiding high carbon decomposition. The SEM images and XRD spectrum indicated that the structure of oxygen carriers used at different temperatures had no obvious agglomeration except at $1000{ }^{\circ} \mathrm{C}$. Further, density functional theory calculations showed that a hybrid occurs at the interface between $\mathrm{Fe}_{2} \mathrm{O}_{3}$ and $\mathrm{Al}_{2} \mathrm{O}_{3}$, with obvious electronic interaction at the interface. The electronic synergy of $\mathrm{Al}_{2} \mathrm{O}_{3}$ promotes the interaction between $\mathrm{CO}$ and the surfaces, hence favoring oxygen transfer from the bulk of iron-based oxygen to the surface during the CLC of $\mathrm{CO}$. However, no evidence could verify that $\mathrm{Al}_{2} \mathrm{O}_{3}$ favors the prevention of carbon deposition on the reduced $\mathrm{Fe}_{2} \mathrm{O}_{3} / \mathrm{Al}_{2} \mathrm{O}_{3}$. These results may provide a fundamental understanding of the relationship between the behavior of $\mathrm{Fe}_{2} \mathrm{O}_{3} / \mathrm{Al}_{2} \mathrm{O}_{3}$ and $\mathrm{CO}$.

Acknowledgments: The authors wish to thank the Fundamental Research Funds for the Central Universities (No. 2016YQ07), National Natural Science Foundation of China (Nos. 51106051, 51206044, 51476056), 111 Project (No. B12034) and the Beijing Natural Science Foundation (No. 3144036).

Author Contributions: Zhiyong Liang contributors to the experiments and writing manuscript; Wu Qin performed the theoretical calculations and participated in the discussions; Changqing Dong participated in the writing and editing of the manuscript.

Conflicts of Interest: The authors declare no conflict of interest.

\section{References}

1. De Diego, L.F.; Garcia-Labiano, F.; Adánez, J.; Gayán, P.; Abad, A.; Corbella, B.M.; Maria Palacios, J. Development of Cu-based oxygen carriers for chemical-looping combustion. Fuel 2004, 83, 1749-1757. [CrossRef] 
2. Wolf, J.; Anheden, M.; Yan, J.Y. Comparison of nickel- and iron-based oxygen carriers in chemical looping combustion for $\mathrm{CO}_{2}$ capture in power generation. Fuel 2005, 84, 993-1006. [CrossRef]

3. Dahl, I.M.; Bakken, E.; Larring, Y.; Spjelkavik, A.I.; Håkonsen, S.F.; Blom, R. On the development of novel reactor concepts for chemical looping combustion. Energy Procedia 2009, 1, 1513-1519. [CrossRef]

4. De Diego, L.F.; Garcia-Labiano, F.; Gayán, P.; Celaya, J.; Palacios, J.M.; Adánez, J. Operation of a 10 kwth chemical-looping combustor during $200 \mathrm{~h}$ with a $\mathrm{CuO}-\mathrm{Al}_{2} \mathrm{O}_{3}$ oxygen carrier. Fuel 2007, 86, 1036-1045. [CrossRef]

5. Dueso, C.; García-Labiano, F.; Adánez, J.; de Diego, L.F.; Gayán, P.; Abad, A. Syngas combustion in a chemical-looping combustion system using an impregnated Ni-based oxygen carrier. Fuel 2009, 88, 2357-2364. [CrossRef]

6. Shen, L.H.; Zheng, M.; Xiao, J.; Zhang, H.; Xiao, R. Chemical looping combustion of coal in interconnected fluidized beds. Sci. Chin. Ser. E 2007, 50, 230-240. [CrossRef]

7. Zhang, Y.; Doroodchi, E.; Moghtaderi, B. Comprehensive study of $\mathrm{Fe}_{2} \mathrm{O}_{3} / \mathrm{Al}_{2} \mathrm{O}_{3}$ reduction with ultralow concentration methane under conditions pertinent to chemical looping combustion. Energy Fuels 2015, 29, 1951-1960. [CrossRef]

8. Franca, R.V.; Thursfield, A.; Metcalfe, I.S. $\mathrm{La}_{0.6} \mathrm{Sr}_{0.4} \mathrm{CO}_{0.2} \mathrm{Fe}_{0.8} \mathrm{O}_{3-\delta}$ microtubular membranes for hydrogen production from water splitting. J. Membr. Sci. 2012, 389, 173-181.

9. Echegoyen, Y.; Suelves, I.; Lázaro, M.J.; Sanjuán, M.L.; Moliner, R. Thermo catalytic decomposition of methane over Ni-Mg and Ni-Cu-Mg catalysts. Appl. Catal. A Gen. 2007, 333, 229-237. [CrossRef]

10. Mattisson, T.; Leion, H.; Lyngfelt, A. Chemical-looping with oxygen uncoupling using $\mathrm{CuO} / \mathrm{ZrO}_{2}$ with petroleum coke. Fuel 2009, 88, 683-690. [CrossRef]

11. Azimi, G.; Leion, H.; Mattisson, T.; Lyngfelt, A. Chemical-looping with oxygen uncoupling using combined Mn-Fe oxides, testing in batch fluidized bed. Energy Procedia 2011, 4, 370-377. [CrossRef]

12. Bermúdez, J.M.; Fidalgo, B.; Arenillas, A.; Menéndez, J.A. $\mathrm{CO}_{2}$ reforming of coke oven gas over a Ni/ $\gamma \mathrm{Al}_{2} \mathrm{O}_{3}$ catalyst to produce syngas for methanol synthesis. Fuel 2012, 94, 197-203. [CrossRef]

13. Wang, B.; Zhao, H.; Zheng, Y.; Liu, Z.; Yan, R.; Zheng, C. Chemical looping combustion of a Chinese anthracite with $\mathrm{Fe}_{2} \mathrm{O}_{3}$-based and CuO-based oxygen carriers. Fuel Process. Technol. 2012, 96, 104-115. [CrossRef]

14. Mei, D.F.; Zhao, H.B.; Ma, Z.J.; Yang, W.J.; Fang, Y.F.; Zheng, C.G. Oxygen release kinetics and mechanism study on Cu-, Co-, Mn-based oxygen carrier. J. Fuel Chem. Technol. 2013, 41, 235-242. [CrossRef]

15. Chen, D.Q.; Shen, L.H.; Xiao, J.; Song, T.; Gu, H.M.; Zhang, S.W. Experimental investigation of hematite oxygen carrier decorated with $\mathrm{NiO}$ for chemical-looping combustion of coal. J. Fuel Chem. Technol. 2012, 40, 267-272. [CrossRef]

16. Aghabararnejad, M.; Patience, G.S.; Chaouki, J. TGA and kinetic modelling of CO, Mn and Cu oxides for chemical looping gasification (CLG). Can. J. Chem. Eng. 2014, 92, 1903-1910. [CrossRef]

17. Wang, B.; Yan, R.; Lee, D.H.; Zheng, Y.; Zhao, H.; Zheng, C. Characterization and evaluation of $\mathrm{Fe}_{2} \mathrm{O}_{3} / \mathrm{Al}_{2} \mathrm{O}_{3}$ oxygen carrier prepared by sol-gel combustion synthesis. J. Anal. Appl. Pyrolysis 2011, 91, 105-113. [CrossRef]

18. Li, K.; Wang, H.; Wei, Y.; Yan, D. Direct conversion of methane to synthesis gas using lattice oxygen of $\mathrm{CeO}_{2}-\mathrm{Fe}_{2} \mathrm{O}_{3}$ complex oxides. Chem. Eng. J. 2010, 156, 512-518. [CrossRef]

19. Gayán, P.; Pans, M.A.; Ortiz, M.; Abad, A.; de Diego, L.F.; García-Labiano, F.; Adánez, J. Testing of a highly reactive impregnated $\mathrm{Fe}_{2} \mathrm{O}_{3} / \mathrm{Al}_{2} \mathrm{O}_{3}$ oxygen carrier for a SR-CLC system in a continuous CLC unit. Fuel Process. Technol. 2012, 96, 37-47. [CrossRef]

20. Gao, Z.P.; Shen, L.H.; Xiao, J.; Zheng, M.; Wu, J.H. Analysis of reactivity of Fe-based oxygen carrier with coal during chemical-looping combustion. J. Fuel Chem. Technol. 2009, 37, 513-520. [CrossRef]

21. Huang, Z.; He, F.; Zhu, H.; Chen, D.; Wei, G.; Feng, Y.; Zheng, A.; Zhao, Z.; Li, H. Thermodynamic analysis and thermogravimetric investigation on chemical looping gasification of biomass char under different atmospheres with $\mathrm{Fe}_{2} \mathrm{O}_{3}$ oxygen carrier. Appl. Energy 2015, 157, 546-553. [CrossRef]

22. Zhang, Y.; Doroodchi, E.; Moghtaderi, B. Reduction kinetics of $\mathrm{Fe}_{2} \mathrm{O}_{3} / \mathrm{Al}_{2} \mathrm{O}_{3}$ by ultralow concentration methane under conditions pertinent to chemical looping combustion. Energy Fuels 2015, 29, 337-345. [CrossRef]

23. Tang, M.; Xu, L.; Fan, M. Progress in oxygen carrier development of methane-based chemical-looping reforming: A review. Appl. Energy 2015, 151, 143-156. 
24. Luo, M.; Wang, S.; Wang, L.; Lv, M. Reduction kinetics of iron-based oxygen carriers using methane for chemical-looping combustion. J. Power Sources 2014, 270, 434-440. [CrossRef]

25. Botas, J.A.; Melero, J.A.; Martinez, F.; Pariente, M.I. Assessment of $\mathrm{Fe}_{2} \mathrm{O}_{3} / \mathrm{SiO}_{2}$ catalysts for the continuous treatment of phenol aqueous solutions in a fixed bed reactor. Catal. Today 2010, 149, 334-340. [CrossRef]

26. Fang, F.; Li, Z.S.; Cai, N.S.; Tang, X.Y.; Yang, H.T. AFM investigation of solid product layers of $\mathrm{MgSO}_{4}$ generated on $\mathrm{MgO}$ surfaces for the reaction of $\mathrm{MgO}_{\text {with }} \mathrm{SO}_{2}$ and $\mathrm{O}_{2}$. Chem. Eng. Sci. 2011, 66, 1142-1149. [CrossRef]

27. Cabello, A.; Dueso, C.; Garcia-Labiano, F.; Gayán, P.; Abad, A.; de Diego, L.F.; Adánez, J. Performance of a highly reactive impregnated $\mathrm{Fe}_{2} \mathrm{O}_{3} / \mathrm{Al}_{2} \mathrm{O}_{3}$ oxygen carrier with $\mathrm{CH}_{4}$ and $\mathrm{H}_{2} \mathrm{~S}$ in a $500 \mathrm{~W}$-th CLC unit. Fuel 2014, 121, 117-125. [CrossRef]

28. Hossain, M.M.; Ahmed, S. Cu-based mixed metal oxide catalysts for WGSR: Reduction kinetics and catalytic activity. Can. J. Chem. Eng. 2013, 91, 1450-1458. [CrossRef]

29. Saha, C.; Zhang, S.; Hein, K.; Xiao, R.; Bhattacharya, S. Chemical looping combustion (CLC) of two Victorian brown coals-Part 1: Assessment of interaction between $\mathrm{CuO}$ and minerals inherent in coals during single cycle experiment. Fuel 2013, 104, 262-274.

30. Xin, J.; Wang, F.; He, F.; Zhang, Z. Thermodynamic and equilibrium composition analysis of using iron oxide as an oxygen carrier in nonflame combustion technology. J. Nat. Gas Chem. 2005, 04, 248-253.

31. Perdew, J.P.; Wang, Y. Accurate and simple analytic representation of the electron-gas correlation energy. Phys. Rev. B 1992, 45, 13244-13249. [CrossRef]

32. White, J.A.; Bird, D.M. Implementation of gradient-corrected exchange-correlation potentials in car-parrinello total-energy calculations. Phys. Rev. B 1994, 50, 4954-4957. [CrossRef]

33. Yang, T.; Wen, X.D.; Ren, J.; Li, Y.W.; Wang, J.G.; Huo, C.F. Surface structures of $\mathrm{Fe}_{3} \mathrm{O}_{4}(111)$, (110), and (001): A density functional theory study. J. Fuel Chem. Technol. 2010, 38, 121-128. [CrossRef]

34. Govind, N.; Petersen, M.; Fitzgerald, G.; King-Smith, D.; Andzelm, J. A generalized synchronous transit method for transition state location. Comput. Mater. Sci. 2003, 28, 250-258. [CrossRef]

35. Zhang, X.; Song, X.; Sun, Z.; Li, P.; Yu, J. Density functional theory study on the mechanism of calcium sulfate reductive decomposition by carbon monoxide. Ind. Eng. Chem. Res. 2012, 51, 6563-6570. [CrossRef]

36. Song, J.; Niu, X.; Ling, L.; Wang, B. A density functional theory study on the interaction mechanism between $\mathrm{H}_{2} \mathrm{~S}$ and the $\alpha-\mathrm{Fe}_{2} \mathrm{O}_{3}(0001)$ surface. Fuel Process. Technol. 2013, 115, 26-33. [CrossRef]

37. Adanez, J.; Abad, A.; Garcia-Labiano, F.; Gayan, P.; de Diego, L.F. Progress in chemical-looping combustion and reforming technologies. Prog. Energy Combust. Sci. 2012, 38, 215-282. [CrossRef]

38. Zhang, S.; Rajendran, S.; Henderson, S.; Zeng, D.; Xiao, R.; Bhattacharya, S. Use of pyrite cinder as an iron-based oxygen carrier in coal-fueled chemical looping combustion. Energy Fuels 2015, 29, 2645-2655. [CrossRef]

39. Dong, C.; Sheng, S.; Qin, W.; Lu, Q.; Zhao, Y.; Wang, X.; Zhang, J. Density functional theory study on activity of $\alpha-\mathrm{Fe}_{2} \mathrm{O}_{3}$ in chemical-looping combustion system. Appl. Surf. Sci. 2011, 257, 8647-8652. [CrossRef]

40. Claridge, J.B.; Green, M.L.H.; Tsang, S.C.; York, A.P.E.; Ashcroft, A.T.; Battle, P.D. A study of carbon deposition on catalysts during the partial oxidation of methane to synthesis gas. Catal. Lett. 1993, 22, $299-305$. [CrossRef]

41. Bao, J.; Liu, W.; Cleeton, J.P.E.; Scott, S.A.; Dennis, J.S.; Li, Z.; Cai, N. Interaction between Fe-based oxygen carriers and N-heptane during chemical looping combustion. Proc. Combust. Inst. 2013, 34, 2839-2846. [CrossRef]

42. Dong, C.Q.; Liu, X.L.; Qin, W.; Lu, Q.; Wang, X.Q.; Shi, S.M.; Yang, Y.P. Deep reduction behavior of iron oxide and its effect on direct CO oxidation. Appl. Surf. Sci. 2012, 258, 2562-2569. [CrossRef]

43. Kierzkowska, A.M.; Bohn, C.D.; Scott, S.A.; Cleeton, J.P.; Dennis, J.S.; Muller, C.R. Development of iron oxide carriers for chemical looping combustion using sol-gel. Ind. Eng. Chem. Res. 2010, 49, 5383-5391. [CrossRef]

44. Hafizi, A.; Rahimpour, M.R.; Hassanajili, S. Calcium promoted $\mathrm{Fe} / \mathrm{Al}_{2} \mathrm{O}_{3}$ oxygen carrier for hydrogen production via cyclic chemical looping steam methane reforming process. Int. J. Hydrogen Energy 2015, 40, 16159-16168. [CrossRef]

45. Zhang, J.; Guo, Q.; Liu, Y.; Cheng, Y. Preparation and characterization of $\mathrm{Fe}_{2} \mathrm{O}_{3} / \mathrm{Al}_{2} \mathrm{O}_{3}$ using the solution combustion approach for chemical looping combustion. Ind. Eng. Chem. Res. 2012, 51, 12773-12781. [CrossRef] 
46. Li, J.; Lin, C.; Qin, W.; Xiao, X.; Wei, L. Synergetic effect of mercury adsorption on the catalytic decomposition of $\mathrm{CO}$ over perfect and reduced $\mathrm{Fe}_{2} \mathrm{O}_{3}$ [001] surface. Acta Phys. Chim. Sin. 2016, 32, 2717-2723.

47. Qin, W.; Lin, C.F.; Long, D.T.; Wang, J.Y.; Dong, C.Q. Activity of $\mathrm{Fe}_{2} \mathrm{O}_{3}$ with a high index facet for bituminous coal chemical looping combustion: A theoretical and experimental study. RSC Adv. 2016, 6, 85551-85558. [CrossRef]

48. Qin, W.; Wang, Y.; Lin, C.; Hu, X.; Dong, C. Possibility of morphological control to improve the activity of oxygen carriers for chemical looping combustion. Energy Fuels 2015, 29, 1210-1218. [CrossRef]

49. Lin, C.F.; Qin, W.; Dong, C.Q. Reduction effect of $\alpha-\mathrm{Fe}_{2} \mathrm{O}_{3}$ on carbon deposition and CO oxidation during chemical-looping combustion. Chem. Eng. J. 2016, 301, 257-265. [CrossRef]

(C) 2017 by the authors. Licensee MDPI, Basel, Switzerland. This article is an open access article distributed under the terms and conditions of the Creative Commons Attribution (CC BY) license (http:/ / creativecommons.org/licenses/by/4.0/). 